\title{
Bentuk Perlindungan Hukum Korban Tindak Pidana Pornografi
}

\author{
Robbil Iqsal Mahendra \\ Magister Ilmu Hukum Universitas Diponegoro \\ Korespondensi : robbiliqsal@gmail.com
}

\author{
Info Artikel \\ Riwayat: \\ Diajukan : 29 Mei2021 \\ Ditelaah : 31 Mei 2021 \\ Direvisi : : 15 Juni 2021 \\ Diterima : 01 Juli 2021 \\ Kata Kunci : \\ korban; perlindungan hukum, \\ pornografi \\ DOI: \\ 10.18196/ijclc .v2i2.12432
}

\begin{abstract}
Abstrak
Semakin majunya teknologi, maka semakin berkembang dan bertambahnya pula metode, teknik, dan cara yang dilakukan oleh masyarakat untuk melakukan kejahatan melalui teknologi tersebut. Pada saat ini kejahatan yang dilakukan di media sosial sangat beragam dan sudah tidak menjadi sesuatu yang tabu lagi, salah satunya dengan meningkatnya kasus kejahatan kesusilaan. Tindak pidana pornografi merupakan salah satu bentuk kejahatan kesusilaan yang disebabkan karena kemajuan teknologi. Tindak pidana pornografi mengalami perkembangan yang sangat pesat dan membuat masyarakat menjadikan media sosial sebagai wadah untuk melakukan kejahatan sekaligus dapat menjadi korban. Seringkali korban dijebak, diperas, dicemarkan nama baiknya, melalui konten pornografi yang diunggah di media sosial. Padahal sudah seharusnya sebagai pengguna teknologi perlu dilindungi baik data maupun kerahasiaannya. Sehingga penelitian ini sangat penting dikaji untuk melihat bagaimana pengaturan terhadap tindak pidana pornografi dan bagaimana perlindungan hukum terhadap terhadap korban dari tindak pidana pornografi. Penelitian ini merupakan penelitian hukum normatif dengan menggunakan studi kepustakaan yang disajikan secara deskriptif. Tujuan dari penulisan ini untuk mengetahui pengaturan terhadap tindak pidana pornografi dan perlindungan hukum terhadap korban. Berdasarkan hasil penelitian, pengaturan terhadap tindak pidana pornografi dapat ditemukan di KUHP, Undang-Undang Pornografi, dan Undang-Undang Informasi dan Transaksi Elektronik. Adapun perlindungan hukum terhadap korban tindak pidana pornografi melalui media sosial antara lain korban mendapatkan bantuan medis dan bantuan rehabilitasi psiko-sosial. Bantuan permohonan tersebut diajukan secara tertulis.
\end{abstract}

\section{Pendahuluan}

Kemajuan ilmu pengetahuan dan teknologi saat ini telah mempengaruhi cara berpikir dan gaya hidup manusia kearah yang lebih modern. Teknologi pada dasarnya diciptakan untuk meningkatkan kualitas hidup serta mempermudah aktivitas manusia agar lebih efektif dan efisien. ${ }^{1}$ Perkembangan kemajuan tersebut membuat masyarakat menjadikannya sebagai sarana untuk melakukan kejahatan. Perkembangan masyarakat ke arah modern telah menyebabkan perkembangan kejahatan yang mencakup jenis serta dimensi yang sebelumnya tidak ada. Semakin modern suatu masyarakat, semakin modern juga metode, teknik dan cara-cara tindak kejahatan yang dilakukan oleh para pelakunya. Salah satu kemajuan teknologi informasi yang diciptakan pada saat ini adalah internet. Teknologi internet membawa manusia pada peradaban baru, dimana terjadi perpindahan realitas kehidupan dari aktifitas nyata ke aktifitas maya (virtual) yang disebut dengan istilah Cyberspace. ${ }^{2}$

Kejahatan yang dilakukan di media sosial kerap kali terjadi dan rasanya sudah tidak menjadi sesuatu yang tabu lagi. Salah satunya tindak pidana pornografi pelecehan seksual yang terjadi di jejaring

\footnotetext{
${ }^{1}$ Fanggi, R.A. (2019). Kebijakan Hukum Pidana Dalam Upaya Penanggulangan Cyberporn. JURNAL HUKUM YURISPRUDENSIA. 17 (2), h. 53.

${ }^{2}$ Andi, H. (1990). Aspek-Aspek Pidana di Bidang Komputer, Jakarta :Sinar Grafika, h. 43.
} 
media sosial yang umumnya merupakan jenis pelecehan tertulis yang bisa menyebabkan atau melatarbelakangi terjadinya pelecehan-pelecehan seksual lainnya. Sasaran empuk dari tindak pidana asusila melalui media sosial adalah para kaum Perempuan. Banyak wanita menjadi korban tindak asusila melalui media sosial karena dominasi laki-laki dalam bermasyarakat. Perempuan akan selalu dijadikan obyek dan tak jarang mengalami kekerasan, pelecehan seksual, penganiayaan, intimidasi, pemerkosaan, dan pembunuhan. Kewajaran ini dianggap dan dipahami oleh masyarakat sebagai wujud dari eksistensi laki-laki dengan segala sikap dominasi. ${ }^{3}$ Ada beberapa pelecehan seksual lainnya yang bisa saja terjadi dari perkenalan lewat jejaring media sosial, antara lain pelecehan fisik, pelecehan lisan, pelecehan isyarat, dan pelecehan emosional. Pelecehan tersebut dapat berdampak trauma berkepanjangan bagi perempuan yang mendapat pelecehan seksual melalui media sosial.

Menurut penelitian yang dilakukan oleh organisasi pemerhati keadilan gender Stop Street Harassment berbasis di Virginia, Amerika, pada tahun 2017 di temukan fakta 81\% perempuan di Amerika Serikat pernah mengalami pelecehan seksual di sepanjang hidupnya. Dalam penelitian lainnya, 3 dari 4 perempuan telah mengalami pelecehan secara verbal atau dengan presentase $77 \%$. Dari berbagai bentuk pelecehan seksual yang dilakukan, setidaknya sebanyak $41 \%$ dilakukan melalui dunia digital. Kebanyakan korban yang mengalami pelecehan seksual yaitu diantara usia 14 hingga 17 tahun. ${ }^{4}$ Di Indonesia sendiri kasus pelecahan seksual pernah dialami oleh Guru Honorer di SMA N 7 Mataram Nusa Tenggara Barat (NTB) yang bernama Baiq Nuril Maknun yang menjadi korban tindak pidana asusila yang dilakukan oleh atasannya berinisial M. M melakukan pelecehan secara verbal dan Baiq Nuril berinisiatif untuk merekam perbincangannya dengan M untuk dijadikan sebagai bukti jika dirinya telah dilecehkan secara verbal sekalipun Baiq Nuril tidak pernah melaporkan rekaman tersebut karena kekhawatirannya jika dia di pecat. Tanpa sengaja kemudian rekaman tersebut tersebar dan menjadikan Baiq Nuril yang seharusnya menjadi korban malah ditetapkan sebagai pelaku dan dinyatakan bersalah karena telah menyebarkan rekaman bermuatan kesusilaan dan dihukum enam bulan penjara serta denda Rp500 juta dalam putusan kasasi Mahkamah Agung (MA). ${ }^{5}$

Rekaman tersebut dianggap melanggar ketentuan Pasal 27 ayat (1) jo Pasal 45 ayat (1) UU ITE yang berbunyi "Setiap orang dengan sengaja dan tanpa hak mendistribusikan dan/atau mentransmisikan dan/atau membuat dapat diaksesnya Informasi Elektronik dan/atau Dokumen Elektronik yang memiliki muatan yang melanggar kesusilaan". Hal ini sangat disayangkan mengingat seharusnya korban mendapatkan perlindungan secara maksimal. Korban sudah mendapatkan pelecehan, trauma, kehilangan pekerjaan, malah dijadikan sebagai pelaku karena ketidak tahuan dan tidak sengaja nya konten tersebut tersebar di media sosial. Sedangkan pelaku pelecehan seringkali di biarkan dan tidak mendapatkan hukuman selayaknya. Hal tersebut yang kemudian menarik untuk Penulis membahas lebih lanjut terkait lingkup pengaturan tindak pidana pornografi dan bagaimana perlindungan hukum yang seharusnya di dapatkan oleh korban.

\section{Metode Penelitian}

Penelitian ini menggunakan jenis penelitian hukum normatif, yaitu penelitian hukum yang meletakkan hukum sebagai sebuah bangunan sistem norma. Sistem norma tersebut mengenai asas-asas norma, kaidah dari peraturan perundang-undangan, putusan pengadilan, perjanjian serta doktrin atau ajaran. ${ }^{6}$ Sumber data yang digunakan dalam penelitian ini meliputi bahan hukum primer berupa dokumen dan peraturan perundang-undangan, bahan hukum sekunder dan bahan hukum tersier. Adapun

3 Dhion Gumilang, Menulis Referensi dari internet, 25 Desember 2019, https://www.rappler.com/indonesia/berita/204637-opini-ruang-aman-perempuan-dunia-maya, (17.05).

4 Meika Arista, Menulis Referensi dari Internet, 26 Desember 2019
http://www.hakasasi.id/article/detail/125?name=Kekerasan+Seksual+Online\%3A+Bukti+Kerentanan+Per empuan+di+Dunia+Maya\%3F (22.24).

5 CNN Indonesia, Menulis Referensi dari internet, 14 Oktober 2019 https://www.cnnindonesia.com/nasional/20181114133306-12-346485/kronologi-kasus-baiq-nurilbermula-dari-percakapan-telepon (14.13)

${ }^{6}$ Fajar, ND.M dan Achmad, Y. (2013). Dualisme Penelitian Hukum Normatif \& Empiris. Yogyakarta : Pustaka Pelajar. h. 34. 
teknik pengumpulan data yang digunakan dalam penelitian ini ialah studi kepustakaan. Hasil dari penelitian yang terkumpul akan dianalisis dengan menggunakan metode deskriptif dengan cara mendeskripsikan atau memberikan gambaran atas subjek dan objek penelitian dari hasil penelitian yang dilakukan peneliti. ${ }^{7}$

\section{Hasil dan Pembahasan}

\subsection{Pengaturan terhadap Tindak Pidana Pornografi}

Pemidanaan bukanlah sekadar masalah tentang proses sederhana memidana seseorang dengan menjebloskannya ke penjara. Refleksi yang paling kecil saja, dengan mudah menunjukkan bahwa memidana sesungguhnya mencakup pula pencabutan (peniadaan), termasuk proses pengadilan itu sendiri. Maka kesepakatan tentang apa pemidanaan itu merupakan hal yang penting sebelum menempatkan perintah (putusan) ke berbagai aplikasi paksaan publik pada individu, entah atas nama kesehatan, pendidikan, ataupun kesejahteraan umum. ${ }^{8}$

Ted Honderich berpendapat bahwa pemidanaan harus memuat tiga unsur. Pertama, pemidanaan harus mengandung semacam kehilangan (deprivation) atau kesengsaraan (distress) yang biasanya secara wajar dirumuskan sebagai sasaran dari tindakan pemidanaan. Kedua, setiap pemidanaan harus datang dari institusi yang berwenang secara hukum pula. Jadi, pemidanaan tidak merupakan konsekuensi alamiah suatu tindakan. Ketiga, penguasa yang berwenang berhak untuk menjatuhkan pemidanaan hanya kepada subjek yang telah terbukti secara sengaja melanggar hukum atau peraturan yang berlaku dalam masyarakatnya. Meskipun demikian, secara umum pemidanaan dapat dirumuskan terbuka sebagai denda (penalty) yang diberikan oleh instansi yang berwenang kepada pelanggar hukum atau peraturan. ${ }^{9}$

Kesulitan dalam mengatasi tindak pidana pornografi antara lain disebabkan oleh adanya pengertian dan penafsiran yang berbeda-beda terhadap pasal-pasal KUHP yang mengatur masalah pornografi, dan dahulu masyarakat lemah dalam merespon pornografi. ${ }^{10}$ Hukum yang menyangkut tindak pidana pornografi dan bagaimana penegakan hukumnya, maka ada beberapa hal yang perlu dilakukan. Pertama mereview dan memperbaharui peraturan perundang-undangan yang diskriminatif terhadap wanita, yang mengurangi kebebasan wanita sebagai korban untuk melapor dan kedua yang menghambat eksekusi hukuman bagi pelaku kekerasan. ${ }^{11}$

Salah satu ketentuan yang mengatur tentang cyber porn di temukan dalam Pasal 282 KUHP dan termasuk sebagai Delik Kesusilaan. Rumusan unsur-unsur tindak pidana dalam Pasal 282 ini dapat digunakan untuk menjerat tindak pidana cyberporn, yaitu sebagai berikut:

1. Menyiarkan

2. Mempertunjukan atau menempelkan di muka umum, tulisan, gambaran atau benda, yang telah diketahui isinya dan yang melanggar kesusilaan

3. Memasukkannya ke dalam negeri, meneruskannya, mengeluarkannya keluar negeri; atau

4. Mempunyainya dalam persediaan

5. Menjadikan hal tersebut sebagai pencarian atau kebiasaan

Undang-Undang Nomor 44 Tahun 2008 tentang Pornografi juga dapat digunakan untuk menjerat pelaku cyberporn. Khususnya pada unsur menyiarkan, mempertontonkan, mempertunjukan atau menjadi model pornografi yang dilakukan melalui media sosial Instagram, seperti Pasal 29, Pasal 30, Pasal 34, Pasal 36, dengan unsur perbuatannya sebagai berikut:

\footnotetext{
${ }^{7}$ Ibid, h. 183

${ }^{8}$ Sholehuddin. (2007). Sistem Sanksi Dalam Hukum Pidana, Jakarta: Raja Grafindo Persada, h. 69.

${ }^{9} \mathrm{Ibid}$, h. 70

${ }^{10}$ Djubaedah, N. (2003). Pornografi dan Pornoaksi Ditinjau dari Hukum Islam. Jakarta : Kencana, h. 128.

${ }^{11}$ Cholili, A. (1996). Tindak Kekerasan Terhadap Wanita. Makalah Seminar Perlindungan Perempuan dari

Pelecehan dan Kekerasan Seksual. Yogyakarta : PPK UGM-Ford Foundation, h.6.
} 
1. Pasal 29: memproduksi, membuat, memperbanyak, menggandakan, menyebarluaskan, menyiarkan, mengimpor, mengekspor, menawarkan, memperjualbelikan, menyewakan, atau menyediakan pornografi;

2. Pasal 30: menyediakan jasa pornografi;

3. Pasal 34: menjadi objek atau model yang mengandung muatan pornografi;

4. Pasal 36: mempertontonkan diri atau orang lain dalam pertunjukan atau di muka umum yang menggambarkan ketelanjangan, eksploitasiseksual, persenggamaan, atau yang bermuatan pornografi;

Namun demikian, Undang-Undang Pornografi tidak memberikan penjelasan secara rinci tentang bagaimana cara menyiarkan, mempertontonkan, maupun menyalahgunakan internet untuk penyebaran pornografi. Berdasarkan pengertian pornografi yang menyatakan media atau sarananya adalah "melalui berbagai bentuk media komunikasi dan/atau pertunjukan di muka umum" maka menurut penulis internet merupakan media komunikasi yang dapat digunakan untuk penyebaran foto maupun video pornografi. Berdasarkan pemaparan diatas, maka seseorang yang melakukan penyebaran terhadap konten seksual melanggar pasal 27 ayat 1 Undang-Undang Republik Indonesia Nomor 19 Tahun 2016 Tentang Informasi dan Transaksi Elektronik yang berbunyi: "Setiap Orang dengan sengaja dan tanpa hak mendistribusikan dan/atau mentransmisikan dan/atau membuat dapat diaksesnya Informasi Elektronik dan/atau Dokumen Elektronik yang memiliki muatan yang melanggar kesusilaan."

Terdapat 3 unsur perbuatan yang dilarang dalam Pasal 27 Ayat (1) UU ITE. Mekipun antara tiga perbuatan itu dipisahkan dengan frasa "dan/atau", tidaklah berarti tiga perbuatan tersebut mempunyai arti yang sama. Logika pencantuman perkataan "dan/atau", bahwa antara tiga tingkah laku tersebut bisa terjadi serentak dalam suatu peristiwa. Bisa juga terjadi salah satu saja. Bila suatu unsur tidak diberikan penjelasan, baik dalam Pasal 1, penjelasan umum maupun penjelasan pasalnya, pertama harus ditafsirkan berdasarkan bahasa (gramatikal). Jika menurut bahasa tidak didapat hal yang sesuai, barulah melihat apa maksud pembentuk Undang-Undang. Bila juga tidak ditemukan, barulah menggunakan cara-cara menafsirkan yang lain. ${ }^{12}$

Terdapat dua objek perbuatan yang sekaligus objek tindak pidana, ialah "Informasi Elektronik" dan "Dokumen Elektronik". Antara dua frasa tersebut dipisahkan dengan kata "dan/atau" mengandung arti, bahwa dalam suatu peristiwa ada satu objek saja, dan bisa jadi pula pada kedua objek. Sementara frasa "yang memiliki muatan yang melanggar kesusilaan" adalah merupakan unsur "keadaan yang menyertai" yang melekat pada objek tindak pidana tersebut. Pada keadaan inilah letak sifat melawan hukumnya perbuatan-perbuatan yang dilarang dalam tindak pidana Pasal 27 Ayat (1). ${ }^{13}$

Adapun analisanya sebagai berikut:

1. Setiap orang disini adalah ditunjukan kepada bahwa pemilik media elektronik yang mengandung konten nudity dan mengarah pada pelanggaran kesusilaan saat mengunggah foto, rekaman suara ataupun video berdurasi pendek.

2. Dengan sengaja yang dapat diartikan bentuk kesengajaan pemilik telah terbukti melakukan dalam hal melaksanakan delik yang diancamkan dalam pasal tersebut.

3. Tanpa hak, disini diartikan sebagai melawan hukum yaitu tanpa adanya hak sendiri (zonder eigen recht), bertentangan dengan hukum pada umumnya (in strijd met het recht in het algemeen), bertentangan dengan hak pribadi seseorang (in strijd met een anders subjectieve recht), bertentangan dengan hukum objektif (tegen het objectieve recht), semua unsur pornografi dalam pengguna media sosial merupakan tindakan yang melawan hukum dan bertentangan dengan hak pribadi seseorang karena mereka telah mempertontonkan hal negatif dalam media massa yang sifatnya umum.

\footnotetext{
${ }^{12}$ Chazawi, A. Dan Ferdian, A. (2015), Tindak Pidana Informasi \& Transaksi Elektronik. Malang: Media Nusa Creative, h.. 28.

${ }^{13}$ Ibid, h. 32
} 
4. Arti mendistribusikan disini adalah bahwa pemilik akun diatas saat mengunggah foto, rekaman suara maupun video, mereka menyalurkan (membagikan, mengirimkan) konten yang mengandung unsur kesusilaan kepada pengguna lain yang menikmatinya.

5. Arti dari mentransmisikan yaitu mengirimkan atau meneruskan pesan dari pemilik akun kepada pengguna akun lain saat mengunggah.

6. Membuat dapat diaksesnya konten pornografi yaitu semua pemilik akun akan dengan mudah mengakses dan mengoperasikan unggahannya yang mengandung konten pornografi, hal ini merupakan tindakan yang dapat dikenakan pidana oleh pasal 27 ayat 1 UU ITE.

7. Informasi elektronik adalah satu atau sekumpulan data elektronik diantaranya meliputi teks, simbol, gambar, tanda-tanda, isyarat, tulisan, suara, bunyi, dan bentuk-bentuk lainnya yang telah diolah sehingga mempunyai arti atau dapat dipahami oleh orang yang mampu memahaminya, dalam pasal ini informasi elektronik yang dimaksud adalah memiliki muatan yang melanggar kesusilaan seperti yang ada pada Instagram.

8. Arti dokumen elektronik adalah setiap Informasi Elektronik yang dibuat, diteruskan, dikirimkan, diterima, atau disimpan dalam bentuk analog, digital, elektromagnetik, optikal, atau sejenisnya, yang dapat dilihat, ditampilkan, dan/atau didengar melalui Komputer atau Sistem Elektronik, tetapi tidak terbatas pada tulisan, suara, gambar, peta, rancangan, foto atau sejenisnya, huruf, tanda, angka, Kode Akses, simbol atau perforasi yang memiliki makna atau arti atau dapat dipahami oleh orang yang mampu memahaminya yang dimuat dengan melanggar kesusilaan yang ditampilkan dalam media sosial Instagram.

9. Memiliki muatan melanggar kesusilaan. Yaitu para pengguna di aplikasi media sosial berlombalomba memberikan konten foto, rekaman suara maupun video yang berpotensi mendapatkan jumlah pengikut (follower). Yang paling sering adalah konten dengan pakaian yang menggoda. Misalnya hanya menggunakan celana pendek, dan pakaian lain yang berpotensi mengumbar aurat dan bagian pribadi dari si pemilik akun. Pakaian yang menggoda itu biasanya diiringi oleh aktivitas yang dilakukan pemilik akun dalam akunya. Seperti menari, dari yang biasa sampai menjurus kearah striptis hingga melakukan adegan asusila dengan lawan jenis seperti berciuman.

Sanksi pidana pasal 27 ayat (1) terdapat pada pasal 45 ayat (1) yaitu hukuman pidana penjara paling lama 6 (enam) tahun dan/atau denda paling banyak Rp. 1.000.000.000,00 (satu miliar rupiah). Seseorang yang dapat dijerat oleh ketentuan Pasal 27 ayat 1 UU ITE ini adalah pihak yang mendistribusikannya, mentransmisikan dan/atau membuat dapat diaksesnya Informasi elektronik dan/atau dokumen elektronik yang mempunyai muatan melanggar kesusilaan. Sedangkan untuk produsen dan pemilik perangkat lunak dan perangkat keras dalam hal program muatan pornografi seperti perusahaan Instagram tidak dijerat dengan pasal ini tetapi dikenakan dengan pasal 34 ayat (1) dan dikenakan sanksi pidana sebagaimana ditentukan dalam Pasal 50 UU ITE dan Transaksi Elektronik. Dimana ancaman pidananya lebih berat daripada pasal 45 yang diperuntukan untuk distributor yaitu pidana penjara paling lama 10 tahun dan/atau denda paling banyak Rp.10.000.000.000,00 (sepuluh miliar rupiah).

\subsection{Perlindungan Hukum Terhadap Korban Pelecehan Seksual melalui Media Sosial}

Tindak pidana Pornografi melalui media sosial merupakan tindak pidana yang dimuat di dalam Undang-Undang Nomor 19 Tahun 2016 tentang Perubahan Atas Undang-Undang Nomor 11 Tahun 2008 tentang Informasi dan Transaksi Elektronik ("UU 19/2016"). Undang-Undang tersebut mengatur mengenai larangan penyebaran informasi elektronik dan/atau dokumen elektronik bermuatan asusila dan dalam Kitab Undang-undang Hukum Pidana (KUHP) pada Buku Kedua BAB XIV tentang Kejahatan Terhadap Kesusilaan. Sebenarnya KUHP tidak mengenal istilah perbuatan seksual, tetapi dikenal dengan perbuatan cabul yang diatur pada Pasal 289 sampai dengan 296 KUHP. Pasal 289 KUHP menyebutkan bahwa barang siapa dengan kekerasan atau ancaman kekerasan memaksa seseorang untuk melakukan atau membiarkan dilakukan perbuatan cabul, diancam karena melakukan perbuatan yang menyerang kehormatan kesusilaan, dengan pidana penjara paling lama sembilan tahun. 
Kemajuan teknologi mampu memberikan kemudahan bagi masyarakat namun juga dapat menyebabkan masyarakat melakukan kejahatan. Salah satu nya kejahatan yang berkaitan dengan tindak pidana asusila. Adapun bentuk tindak pidana asusila yang menggunakan media sosial seperti: ${ }^{14}$

1. Perbuatan tindak pidana asusila dengan mengirimi pesan tidak senonoh

2. Perbuatan tindak pidana asusila dengan menelpon serta membahas konten seksual

3. Perbuatan tindak pidana asusila dengan ajakan serta imbalan untuk melakukan aktivitas seksual

Berdasarkan pengertian dalam Undang-Undang Nomor 31 Tahun 2014 Tentang Perubahan Atas Undang-Undang Nomor 13 Tahun 2006 Tentang Perlindungan Saksi dan Korban, korban adalah seseorang yang mengalami penderitaan, baik fisik, mental dan ekonomi saja. Namun tidak menutuo kemungkinan, dalam satu waktu korban dapat mengalami ketiganya sekaligus. Adapun dampak atau kerugian yang dirasakan oleh korban akibat dari pelecehan secara seksual antara lain:15

1. Dampak Secara Fisik

Yaitu seperti infeksi pada alat kelamin, infeksi pada panggul, sakit ketika berhubungan seksual, kesulitan buang air besar, luka pada dagu, menderita migran, sulit tidur, dan lain-lain.

2. Dampak Secara Mental

Yaitu seperti sangat takut sendirian, takut pada orang lain, nervous, ragu-ragu (kadang paranoia), sering terkejut, sangat khawatir, sangat hati-hati dengan orang asing, sulit mempercayai seseorang, tidak percaya lagi pada pria, takut pada pria, takut akan seks, merasa bahwa orang lain tidak menyukainya, dingin (secara emosional), sulit berhadapan dengan publik dan teman-temannya, membenci apa saja, menarik diri/ mengisolasi diri, mimpi-mimpi buruk, dan lain-lain.

3. Dampak Dalam Kehidupan Pribadi dan Sosial

Yaitu seperti ditinggalkan teman dekat, merasa dikhianati, hubungan dengan suami memburuk, tidak menyukai seks, sulit jatuh cinta, sulit membina hubungan dengan pria, takut bicara dengan pria, menghindari setiap pria, dan lain-lain.

Korban yang dihadapkan pada proses pengadilan juga mengalami penderitaan karena diharuskan untuk mengulangi atau menceritakan kembali derita yang dirasakan. Proses tersebut terbagi sebagai berikut: 16

1. Sebelum Sidang Pengadilan

Dalam keadaan sakit dan terganggu mental serta jiwanya korban berusaha untuk membuat laporan kepada polisi. Hal tersebut dilakukan oleh korban sebagai bagian dari pengumpulan bukti dengan menceritakan kembali kejadian yang menimbulkan trauma kepada polisi. Tidak jarang korban juga merasa ketakutan karena mendapatkan ancaman dari pelaku.

2. Selama Sidang Pengadilan

Dalam kondisi yang masih trauma terkadang korban berusaha untuk tetap hadir di persidangan pengadilan sebagai saksi. Namun tanpa disadari kehadiran korban dalam persidangan justru akan semakin membuka trauma secara emosional karena korban dalam memberikan kesaksian harus mengulangi cerita terhadap pelecehan seksual yang di alami. Dalam kesempatan yang sama, korban juga harus di hadapkan kepada pelaku yang telah melakukan pelecehan seksual kepadanya. Tidak jarang pembelaan atau keterangan dari pelaku justru menyudutkan korban dan menjadikan korban memiliki andil atas kejahatan yang terjadi. Posisi korban sendiri di wakili oleh Jaksa, namun kadang tidak dapat memberikan keuntungan atau perlindungan yang

\footnotetext{
${ }^{14}$ Makmuri, (2020), Implementasi Perlindungan Hukum Terhadap Perempuan Sebagai Korban Tindak Pidana Pelecehan Seksual Dalam Transportasi. Skripsi. Fakultas Hukum. Universitas Pancasakti. Tegal.HIm.57

${ }^{15}$ Santoso, T (1997). Seksualitas dan Hukum Pidana, Jakarta : IND.HILL-CO, h. 40.

${ }^{16}$ Gosita, A. (1987). Relevansi Viktimologi Dengan Pelayanan Terhadap Para Korban Perkosaan, Jakarta : IND.HILL-CO, h. 13.
} 
maksimal bagi korban. Sehingga sangat penting kedudukan pendamping bagi korban dalam menghadapi proses peradilan.

3. Setelah Sidang Pengadilan

Ketika pelaku sudah di vonis bersalah, dan menjalani hukuman di Lembaga pemasyarakatan, kedudukan korban seringkali terlupakan terutama yang berkaitan dengan ganti kerugian atas kejadian yang menimpa korban. Korban terpaksa harus menanggung penderitaannya sendiri, dan bertanggung jawab atas apa yang terjadi pada dirinya. Tidak jarang korban dihantui rasa trauma, takut, yang tidak hilang, karena tidaknya pemulihan yang diberikan kepada korban.

Hak-hak korban dapat dilihat dari ketentuan Pasal 5 ayat (1) Undang-Undang Nomor 31 Tahun 2014 Tentang Perubahan Atas Undang-Undang Nomor 13 Tahun 2006 Tentang Perlindungan Saksi dan Korban mengatur beberapa hak yang diberikan kepada saksi dan korban, antara lain: ${ }^{17}$

1. Memperoleh perlindungan atas keamanan pribadi, keluarga, dan harta bendanya, serta bebas dari ancaman yang berkenaan dengan kesaksian yang akan, sedang, atau telah diberikannya

2. Ikut serta dalam proses memilih dan menetukan bentuk perlindungan dan dukungan keamanan

3. Memberikan keterangan tanpa tekanan

4. Mendapat penerjemah

5. Bebas dari pertanyaan yang menjerat

6. Mendapat informasi mengenai perkembangan kasus

7. Mendapatkan informasi mengenai putusan pengadilan

8. Mendapat indormasi dalam hal terpidana dibebaskan

9. Dirahasiakan identitasnya

10. Mendapat identitas baru

11. Mendapat tempat kediaman sementara

12. Mendapat tempat kediaman baru

13. Memperoleh penggantian biaya transportasi sesuai dengan kebutuhan

14. Mendapat nasihat hukum

15. Memperoleh bantuan biaya hidup sementara sampai batas waktu perlindungan berakhir; dan/atau

16. Mendapat pendampingan

Dalam kasus tindak pidana asusila selain mendapatkan hak-hak diatas, korban mendapatkan hak menjadi saksi dan memberikan kesaksian di muka persidangan. Hal tersebut memberikan kemudahan dalam hal pembuktian dimana keterangan seorang saksi korban saja sudah dapat dijadikan alat bukti yang sah disamping alat bukti lainnya, seperti alat bukti surat visum et repertum ataupun keterangan dari seorang ahli seperti dokter ataupun psikolog. ${ }^{18}$

Berdasarkan penjelasan di atas, dapat disimpulkan bahwa bentuk-bentuk perlindungan terhadap korban kejahatan dapat didasarkan pada dampak atau kerugian yang dirasakan oleh korban. Pada umumnya, perlindungan tersebut antara lain:19

1. Restitusi

Bentuk perlindungan ini di dasari dari ketentuan Pasal 1 ayat (5) Peraturan Pemerintah Republik Indonesia Nomor 44 Tahun 2008 tentang Pemberian Kompensasi, Restitusi, dan Bantuan Kepada

\footnotetext{
${ }^{17}$ Ibid. HIm.65

18 Ibid. HIm65.

${ }^{19}$ Ibid. hlm67-68
} 
Saksi dan Korban. Restitusi merupakan bentuk ganti kerugian yang diberikan oleh pelaku kepada korban, keluarganya atau pihak ketiga. Ganti kerugian tersebut seperti pengembalian harta milik, pembayaran ganti kerugian atas kehilangan atau penderitaan yang dirasakan dan bisa juga berupa penggantian biaya untuk tindakan tertentu. Restitusi dapat dimohonkan baik oleh korban, keluarga, atau kuasanya berdasarkan surat kuasa khusus tertulis dalam bahasa Indonesia dan bermaterai. Permohonan restitusi tersebut diajukan kepada pengadilan (court, rechtsspraak) melalui Lembaga Perlindungan Saksi dan Korban. Restitusi sendiri bertujuan agar kerugian yang dirasakan oleh korban dapat ditanggulangi dengan baik. ${ }^{20}$

2. Bantuan Medis dan Bantuan Rehabilitas Psiko-Sosial

Bantuan ini di dasari dari ketentuan Undang-Undang Nomor 31 Tahun 2014 tentang Perubahan Atas Undang-Undang Nomor 13 Tahun 2006 tentang Perlindungan saksi dan Korban. Korban berhak mendapatkan bantuan baik secara medis maupun bantuan rehabilitasi psiko-sosial. Bantuan yang dimaksud dapat diberikan oleh Lembaga Perlindungan Saksi dan Korban. Korban atau pun yang mewakili dapat mengajukan permohonan untuk mendapatkan bantuan medis maupun bantuan rehabilitasi psiko-sosial. Permohonan tersebut dapat diajukan secara tertulis dalam bahasa Indonesia bermaterai kepada Lembaga Perlindungan Saksi dan Korban.

3. Perlindungan dari Keluarga

Keluarga perlu memberikan dukungan kepada korban, terlebih keluarga adalah bagian terdekat dari korban sehingga diharapkan dapat lebih memahami kondisi korban. Keluarga dapat memberikan dorongan dan motivasi agar korban tidak larut dalam kesedihan maupun masalah yang dihadapinya. Keluarga harus memberikan keyakinan kepada korban bahwa apa yang terjadi padanya tidak boleh sampai merusak masa depan, dan jangan sampai menurunkan semangat korban. Keluarga juga memiliki peran penting karena mampu menolong korban agar terlepas dari cibiran atau stigma dari masyarakat

4. Perlindungan dari Masyarakat

Masyarakat juga memiliki peran penting dalam membantu memulihkan kondisi kejiwaan korban. Masyarakat harus mampu mengayomi dan melindungi korban dengan tidak memberikan stigma, mengucilkan korban, dan tidak menjauhi korban.

\section{Simpulan}

Pengaturan terhadap tindak pidana pornografi dapat ditemukan dalam KUHP, Undang-Undang Pornografi, dan Undang-Undang Informasi dan Transaksi Elektronik. Sedangkan, bentuk Perlindungan Hukum Terhadap Perempuan Korban Tindak Pidana Pornografi Melalui Media Sosial Menurut UndangUndang Nomor 31 Tahun 2014 tentang Perubahan Atas Undang-Undang Nomor 13 Tahun 2006 tentang Perlindungan saksi dan Korban, korban tindak pelecehan dan/atau kekerasan seksual juga berhak mendapatkan bantuan medis dan bantuan rehabilitasi psiko-sosial. Bantuan tersebut adalah layanan yang diberikan kepada korban dan/atau saksi oleh Lembaga Perlindungan Saksi dan Korban. Permohonan bantuan medis dan bantuan rehabilitasi psiko-sosial dapat diajukan oleh korban, keluarga korban, dan kuasanya dengan surat kuasa khusus. Permohonan diajukan secara tertulis dalam bahasa Indonesia dan diatas kertas bermaterai kepada Lembaga Perlindungan Saksi dan Korban. Disamping itu perlu diperhatikan pula hak-hak korban yang terdapat dalam Pasal 5 yang terdapat pada undang-undang tersebut.

\footnotetext{
${ }^{20}$ Mulyadi, L. (2008). Bunga Rampai Hukum Pidana Prespektif, Teoritus, dan Praktik. Bandung: Alumni. h. 253-254
} 


\section{Daftar Pustaka.}

\section{Buku}

Bungin, B. (2005). Sosiologi Media Konstruksi Sosial Teknologi Telematika Dan Perayaan Seks Di Media Massa. Jakarta: Pernada Mendua

Chazawi, A Dan Ferdian, A. (2015), Tindak Pidana Informasi \& Transaksi Elektronik. Malang: Media Nusa Creative

Cholili, A. (1996). Tindak Kekerasan Terhadap Wanita. Makalah Seminar Perlindungan Perempuan dari Pelecehan dan Kekerasan Seksual. Yogyakarta : PPK UGM-Ford Foundation

Djubaedah, N. (2003). Pornografi dan Pornoaksi Ditinjau dari Hukum Islam. Jakarta : Kencana

Fajar, M dan Achmad, Y. (2013). Dualisme Penelitian Hukum Normatif \& Empiris. Yogyakarta : Pustaka Pelajar.

Gosita, A. (1987). Relevansi Viktimologi Dengan Pelayanan Terhadap Para Korban Perkosaan. Jakarta : IND.HILL-CO.

Hamzah, A. (1990). Aspek-Aspek Pidana di Bidang Komputer. Jakarta : Sinar Grafika.

Huda, C. (2015). 'Tiada Pidana Tanpa Kesalahan' Menuju Kepada 'Tiada Pertanggungjawaban Pidana Tanpa Kesalahan'. Jakarta : Prenadamedia Group

Mulyadi, L. (2008). Bunga Rampai Hukum Pidana Prespektif, Teoritis, dan Praktik. Bandung: Alumni

Santoso, T. (1997). Seksualitas dan Hukum Pidana. Jakarta : IND.HILL-CO.

Sholehuddin. (2007). Sistem Sanksi Dalam Hukum Pidana. Jakarta: Raja Grafindo Persada

Jurnal

Fanggi, R.A. (2019). Kebijakan Hukum Pidana Dalam Upaya Penanggulangan Cyberporn. JURNAL HUKUM YURISPRUDENSIA. 17 (2)

\section{Skripsi}

Makmuri, (2020), Implementasi Perlindungan Hukum Terhadap Perempuan Sebagai Korban Tindak Pidana Pelecehan Seksual Dalam Transportasi. Skripsi. Fakultas Hukum. Universitas Pancasakti. Tegal

\section{Website}

Dhion Gumilang. (2019). Ruang Aman Perempuan Dunia Maya. Diakses pada tanggal 25 Desember 2019, https://www.rappler.com/indonesia/berita/204637-opini-ruang-aman-perempuan-dunia-maya,

Komnas HAM, Diakses pada tanggal, 25 Desember 2019, https://www.komnasperempuan.go.id/aboutprofile-komnas-perempuan,

Meika Arista, Kerentanan Perempuan di Dunia Maya, Diakses pada tanggal 26 Desember 2019, http://www.hakasasi.id/article/detail/125?name=Kekerasan+Seksual+Online\%3A+Bukti+Kerenta nan+Perempuan+di+Dunia+Maya\%3F,

CNN Indonesia, Kronologu Kasus Baiq Nuril, Bermula dari ecakapan telepon, Diakses pada tanggal 14 Oktober 2019, https://www.cnnindonesia.com/nasional/20181114133306-12-346485/kronologikasus-baiq-nuril-bermula-dari-percakapan-telepon 